\title{
Analysis of Biologi Teaching Material in Senior High School Learning Biology Process in Surakarta
}

\author{
N D Yanti ${ }^{1}$, Maridi $^{2}$, Sutarno $^{3}$ \\ 1,2,3Postgraduate Biology Education,Sebelas Maret University, Surakarta \\ \{1noviadamai9@gmail.com, ${ }^{2}$ maridi@staff.uns.ac.id, ${ }^{3}$ nnsutarno@staff.uns.ac.id\}
}

\begin{abstract}
The skills needed in the 21st century are 1) ways of thinking; 2) how to work; 3) tools for work and 4) skills to live in the world. The purpose of this study is to find out the teaching materials used in the learning process at school. Data collected through online classes and high school observations in Surakarta in eight components of the national education standard obtained the highest gap, namely the standard of a process with a percentage of $11.57 \%$, percentage of infrastructure facilities $10.65 \%$. The results of the needs analysis show that the teaching materials used by teachers were obtained from several publishers that did not accommodate students' thinking processes, teaching materials from the Surakarta District MGMP,student worksheets and student reference books. Based on these problems, the innovations needed in biology learning are teaching materials in the form of modules.
\end{abstract}

Keywords: Biology Teaching Material, Learning Biology Process

\section{INTRODUCTION}

The 21th century challenge is finding out and developing tool which add efficiency and value for teaching and learning [1]. Based on the rule no 4/2007 about national standard of learning process suggests lesson plan, teaching material and teaching media as learning essence for students. Teacher is demanded to be able to give quality lesson by creating valid and effective lesson plan and practical tool [2]. Science (biology) education has objective to help the students to participate in discussion, to be able to give argument about the problem happened [3]. Learning process in the class need teaching material that can support the students' thinking process. Module is a teaching material used by the students independently in flexible time without the teacher's guidance [2]. According to [4], module is a systematic teaching material with understandable language to understand which is suited with the students' knowledge and age and used for independent learning without teacher's direct involvement. In addition, it is in line with [3] stating that module will help the students to be clever in communicate in certain area. Module is teaching material with specific material composed systematically functioning to help the students in achieving the learning objectives [5]. With biology module, the students become cleverer in acting, more critical and module can help the students to face the problem they have [3]. learning module can make the lesson more interesting and decrease the students' dependence towards the teacher because the students are demanded to be more independent and active in learning every competency that 
should be mastered [6]. Module functions as supplement that helps the teacher to transfer material and information during the learning process. By the availability of teaching material, the lesson in the class can run well both for the knowledge and skill had to achieve the learning objective. Teaching material in the form of module should have characteristics as follows: (a) self instruction, (b) independent, (c) stand alone, (d) adapted, and (e) friendly user [5]. Biology module uses some design principles that can be descended from social constructivism perspective about learning [3].

Based on this case, the obstacles happened in the school is in the process standard, that is the availability of teaching material used by the teacher during the learning process. It is affected by internal and external factor. In evaluating teaching material, we use SNP (Standar Nasional Pendidikan or Education National Standard), questionnaire of teacher and students' need analysis, teacher and students' interview sheet and evaluation sheet of teaching material (book and module).The benefits of evaluating the teaching material by using SNP, questionnaire of teacher and students' need analysis, teacher and students' interview sheet and evaluation sheet of teaching material are 1) researcher can evaluate the teaching material used by the teacher in detail, 2) the researcher can assess the media used in detail, 3) we know whether the material order is based on the lesson plan made by the teacher or not, 4) it gets the agreement between the text book and Permendiknas, and 5) the researcher can evaluate the teaching material per each indicator. Based on the explanation above, the researcher used SNP and teaching material evaluation sheet used by the school in Surakarta during the biology teaching learning process. The teaching material existed in the school was still the material collection from publisher, so it less trains students' thinking. Teaching materials consisted of common material actually have already developed in the lesson books.

\subsection{Research Method}

This research was qualitative. Method used was qualitative gotten through teaching material evaluation instrument by using SNP, questionnaire of teacher and students' need analysis, teacher and students' interview sheet and evaluation sheet of teaching material. The result of the evaluation was analyzed to know the fulfillment of the teaching material used by the teacher during the lesson process. The sampling technique was purposive sampling. Taking the sample was based on certain consideration. It is more efficient way if it is used correctly and better than random sampling technique [7]. Subject of this research was first semester students of grade X IPA in SMA Negeri Surakarta. The sample used was 27 students consisted of students grade X. In collecting the data, it used SNP instruments consisted of process standard, and means and infrastructure standard with 10 indicators. Questionnaire of teacher and students' need analysis consisted of 9 questions. Interview sheet was with 2 questions, and teaching material evaluation sheet was with 11 material indicators. Furthermore, the data were nalyzed by using descriptive qualitative analysis. The agreement score between the teaching material and the reference existing was measured by using the following formula:

The agreement score of module component $=\frac{\text { total score obtained }}{\text { maximum score }} \times 100 \%$

The measurement result was put into the percentage based on the criteria that had been decided. The basic used to evaluate the agreement of biology teaching material can be seen as in the Table 1 below. 
Tabel 1. Criteria of evaluation qualification towards teaching material

\begin{tabular}{cl}
\hline Average score & Valid Criteria \\
\hline $76 \%-100 \%$ & Very Decent \\
$51 \%-75 \%$ & Decent \\
$26 \%-50 \%$ & Not feasible \\
$0 \%-25 \%$ & Very unworthy \\
\hline Adapted from $[8]$ &
\end{tabular}

\subsection{Result and Discussion}

Teaching material in the form of module is the learning source which helps teacher in sharing information and material in a learning process in order to be able to train ability, skill and knowledge until achieve the learning objective [5]. Module is set by using understandable language, so the teacher and students can use and can develop the students' ability [9]. By the availability of module as the teaching material, the lesson in the class can run well, so the students are more active, and it gives the students opportunity to finish the problem happened [10]. Based on the result of teaching material analysis used in the teaching learning process of biology in SMA Negeri Surakarta by using SNP instrument, questionnaire of teacher and students' instrument, teacher and students' interview sheet, and teaching material evaluation sheet (book and module), it is gotten the following result:

Table 2. Level of eight education national standard (SNP) fulfillment

\begin{tabular}{|c|c|c|c|c|c|c|c|c|c|}
\hline & Total & Score & Contribution & Implementation & Snp & Gap & & Score & \\
\hline & Indikator & Ideal & $\%$ & Score & $\%$ & $\%$ & Min & Max & Mean \\
\hline Standar 1 & 8 & 24 & 11,11 & 15 & 6,94 & 4,17 & 1 & 3 & 1,88 \\
\hline Standar 2 & 10 & 30 & 13,89 & 5 & 2,31 & 11,57 & 1 & 3 & 0,50 \\
\hline Standar 3 & 12 & 36 & 16,67 & 15 & 6,94 & 9,72 & 3 & 3 & 1,25 \\
\hline Standar 4 & 11 & 33 & 15,28 & 11 & 5,09 & 10,19 & 1 & 3 & 1,00 \\
\hline Standar 5 & 11 & 33 & 15,28 & 10 & 4,63 & 10,65 & 3 & 3 & 0,91 \\
\hline Standar 6 & 4 & 12 & 5,56 & 4 & 1,85 & 3,70 & 3 & 3 & 1,00 \\
\hline Standar 7 & 3 & 9 & 4,17 & 3 & 1,39 & 2,78 & 2 & 3 & 1,00 \\
\hline Standar 8 & 13 & 39 & 18,06 & 20 & 9,26 & 8,80 & 1 & 3 & 1,54 \\
\hline Total & 72 & 216 & 100,00 & 83 & 38,43 & 61,57 & & & \\
\hline
\end{tabular}

Based on the table 2 above, it can be concluded that the achievement towards the eight components of SNP in SMA Negeri Surakarta had the highest gap that was in standard 2 of process standard with percentage $11.57 \%$. Therefore, it indicates that the indicator had by the process standard was that the learning media were less optimized by the teacher, so in learning process the students were less accommodated. According to [5], teaching material in the form of module is a learning source which helps the teacher to share information and material in a learning process until achieving learning objectives. Moreover, the next process standard indicator was that every teacher in education unit had duty to make complete and systematic lesson plan, and the application of the lesson was referred to the lesson plan in order that the lesson lasted interactively, inspirationally, fun, in challenge, and could motivate the students to participate actively and creatively. Hence, teaching material used by the teacher had to be sourced from the lesson plan and syllabus. 
Standard 5 was means and infrastructure standard. Indicator had was the agreement between the lesson book and Permendiknas, in which there was unbalance between ideal score and the real score, that was $10.64 \%$ that was caused by the minimum availability of teacher and students' textbook consisted of material indicators which were suited with the teacher Permendiknas. Teacher as the professional educator in doing the duty needs to understand and do the regulation or rules of the law which is related to the duty directly, that are Permendiknas no. 22 and 23/2006 about content standard and SKL, Permendiknas no. 41/2007 about process standard, Permendiknas no. 16/2007 about educator and education officer standard, and Permendiknas no. 20/2007 about evaluation standard. To achieve score $100 \%$, the fulfillment of SNP based on the criteria determined needs support of hard working and high working culture from all school elements, which can only be real with high motivation based on either intrinsic school personal or the extrinsic one in the form of the relevant training.

The following is the graph between ideal score and the real SNP in SMA Negeri Surakarta.

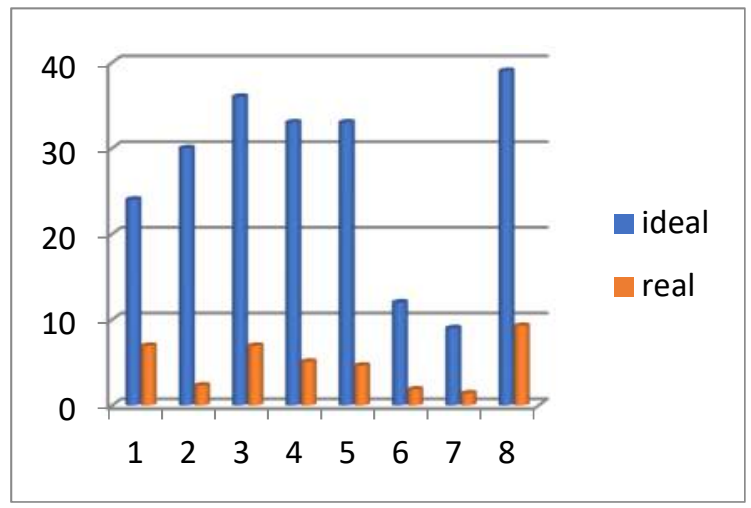

Figure 1. ideal score and the real SNP in SMA Negeri Surakarta.

Based on the graph of comparing percentage above, eight SNP could give clear show between the ideal and the real score. There were eight SNP used to evaluate teaching material. It shows the high gap clearly between the ideal and the real score in the process standard with percentage $11.57 \%$ and means and infrastructure standard with percentage $10.65 \%$. Based on the statement above, therefore, it can be said there was minimum availability of the teacher and students' text book consisted of material indicators which were based on Permendiknas.

In the application of lesson needs a teaching material which can support students in learning. one of the lesson tools used by the teacher is lesson module which can make the lesson interesting and decrease students' dependence towards the teacher, and make the students learn independently and give easiness to the students to learn every material [6]. In addition, it is in line with study by [11] stating that module helped the students to learn abstract physics concept suited with technology and students' learning style, so it could accommodate the learning process.

\subsection{Analysis of teacher and students' needs}

Instrument used in evaluating the teacher's need was by using some questions in total 5 questions, and the students' need analysis was with 6 questions. The questions were used to 
know the teaching material used by the teacher and students during the lesson process, and to find out whether the teaching material was good or not, and the students needed the teaching material which could support their learning. Based on the questions asked to the teacher and students, it seems that they only used the books from publisher without knowing whether every aspect existed in the material indicator had been fulfilled or not yet. Another supporting book was only students' work sheet spread in market. In conclusion, the teaching material used could not fulfill the lesson and accommodate the students' thinking skill.

\begin{tabular}{|c|c|c|c|c|c|}
\hline $\begin{array}{l}\text { A } \\
\text { B } \\
K\end{array}$ & $\begin{array}{l}\text { Aspects evaluated } \\
\text { Indicator }\end{array}$ & Goal & Material & Activity & $\begin{array}{l}\text { Evaluation } \\
\text { item }\end{array}$ \\
\hline $\begin{array}{l}\text { E } \\
\text { V } \\
\text { A } \\
\text { L } \\
\text { U } \\
\text { A } \\
\text { T } \\
\text { I } \\
\text { O } \\
\text { N }\end{array}$ & $\begin{array}{l}\text { Determining ways of overcoming } \\
\text { negative impact of environment change } \\
\text { Explaining ways to overcome the } \\
\text { negative impact of environment change } \\
\text { Comparing preventive ways of the } \\
\text { negative impact of environment change } \\
\text { Comparing ways to overcome the } \\
\text { negative impact of environment change } \\
\text { Determining ways to overcome the } \\
\text { negative impact of environment change } \\
\text { Explaining ways to overcome the } \\
\text { negative impact of environment change } \\
\text { Comparing preventive ways of the } \\
\text { negative impact of environment change } \\
\text { Comparing ways to overcome the } \\
\text { negative impact of environment change } \\
\text { Determining environment conservation } \\
\text { Determining ways of environment } \\
\text { waste recycle } \\
\text { Explaining ways of environment waste } \\
\text { recycle to be economic } \\
\text { Comparing ways of environment waste } \\
\text { recycle to be economic }\end{array}$ & $\sqrt{ }$ & $\begin{array}{l}\sqrt{ } \\
\sqrt{ }\end{array}$ & & $\begin{array}{l}\sqrt{ } \\
\sqrt{ }\end{array}$ \\
\hline
\end{tabular}

Based on the result above, we could determine that the result of students' teaching material of grade X IPA at SMA Negeri Surakarta showed that the number of teaching material was still few, and it used had not accommodated the students' thinking skill. Thus, it indicates that there had been great change in biology lesson process. The change can be done through the development of the teaching material functioning to serve teacher and student to do the lesson which can optimize high order thinking, so they can solve problem. Furthermore, based on the study like resulted by Disendjaja \& Romlah, the result showed that in Indonesia the teacher only used one book during the lesson, at least, the school should provide teaching materials based on the number of the students, so biology material should perform science as dynamic study, not as collection of facts and terms [12]. therefore, if the students are not facilitated with more teaching material, there will be many students who are difficult to develop their skill, for by the existence of teaching material can apply skill and knowledge by showing the students' competency during the lesson [5]. Moreover, it is in line with study 
from Syafii \& Yasin, problem-based module in biology lesson could encourage the teacher to give more problem-based contents, and learning by module could be used as tool to help in increasing students' motivation and help the teacher conduct the teaching learning process well in the class [13]. Besides, based on the study from [3], by the existence of small module could bring some changes to attitude. According [9], by the availability of module in lesson could attract students' interest in applied bioinformatics, and it was effective for students in all preparedness levels measured with university criteria overall. Based on the research by [14], it shows that the use of biology module in PTechLS could increase students' performance. The interview result towards biology teacher explained that the use of module could support lesson process as the teaching material. There was possibility that PtechLS could be used in other senior high schools in the country in Malaysia to increase achievement and interest towards biology. The research [15] showed module used in effective learning showed through PBL activities which were included in high category dan the increase of average score of cognitive ability. Even the need of teaching material was really needed in lesson process, so the students could completely understand the concept and apply it to solve related problem as well as respect the strength and creation of God. Basically, biology lesson has specific study characteristic which is different from others. According Carin \& Evans (1990), the biology lesson at least consists of 4 things, they are content, process, attitude and technology. Biology as process means a process or method to get knowledge. to get it, the students should be given a teaching material that can support thinking process, and it should be scientific approach [16]. Science learning is a skill using logic principle and has valid proof and is combined with scientific method in order to get the new knowledge. It is like Ilmu Pengetahuan Nasional Asosiasi Guru (Teacher Association OF national Science) stating that science learning is a learning process encouraged on students' experience combined with the students' thinking skill to solve problem [17]. Science module could help the students of senior high school to be cleverer in their attitude towards the materials being learnt. Based on this argument, it can be concluded that it needs to develop teaching material that is biology module which can support biology lesson. It is in line with the main goal of learning with module that is to increase the efficiency and effectiveness optimally. Learning by module enables the students to increase their learning activities optimally based on the ability and achievement level obtained during the lesson process [18].

\section{CONCLUSIONS}

Teaching materials used by students in class X IPA in Surakarta High School have not been optimized. Evidenced by several instruments used in assessing teaching materials used that teaching materials used by teachers and students have not supported learning and have not been able to accommodate students' thinking abilities. Suggestions, the use of teaching materials can support learning that is equipped with models that train high-level thinking skills.

\section{REFERENCES}

[1] N. Srisawasdi, "The Role of TPACK in Physics Classroom: Case Studies of Preservice Physics Teachers," Procedia - Soc. Behav. Sci., vol. 46, pp. 3235-3243, 2012.

[2] W. A. Marszalek, "The New Educational Reseach," vol. 46, no. 4, 2016.

[3] T. Klop, S. E. Severiens, M. C. P. J. Knippels, M. H. W. van Mil, and G. T. M. Ten 
Dam, "Effects of a science education module on attitudes towards modern biotechnology of secondary school students," Int. J. Sci. Educ., vol. 32, no. 9, pp. 1127-1150, 2010.

[4] I. Mubarok, S. M. E. Susilowati, and N. K. Dewi, "Developmeny of Ecosystem Subject Module With Sets-Vision and Islamic Value," Int. Conf. Math. Sci. Educ. 2015 (ICMSE 2015), vol. 2015, no. Icmse, p. BE 45-BE 50, 2015.

[5] Z. Ariefiani, D. Kustono, and S. Pathmantara, "Module development with project-based learning approach and assure development model," AIP Conf. Proc., vol. 1778, 2016.

[6] S. Heryeni, M. Natalina, and W. Syafi, "the Development Learning Module Biology Ipa Scientific Oriented Approach for Improved Critical Thinking on the Structure of Plants and Materials Utilization in Technology in Class Viii Smp," pp. 1-13.

[7] M. D. C. Tongco, “126-454-1-Pb,” Ethnobot. Res. Appl., vol. 5, pp. 147-158, 2007.

[8] S. Kantun, Y. Sri, and R. Budiawati, "Analisis Tingkat Kelayakan Bahan Ajar Ekonomi Yang Digunakan Oleh Guru Di Sma Negeri 4 Jember,” J. Pendidik. Ekon., vol. 9, no. 2, p. 136, 2015.

[9] A. Madlung, "Assessing an effective undergraduate module teaching applied bioinformatics to biology students," PLoS Comput. Biol., vol. 14, no. 1, pp. 1-15, 2018.

[10] O. Kehidupan and D. I. Smp, "Unnes Journal of Biology Education MEDIA," vol. 1, no. 3, pp. 211-218, 2012.

[11] Norlidah Alias, Saedah Siraj, D. Dewitt, Mohammad Attaran, and Abu Bakar Nordin, "Evaluation on the usability of Physics module in a secondary school in Malaysia: Students' retrospective," Malaysian Online J. Educ. Technol., vol. 1, no. 1, pp. 44-53, 2013.

[12] Y. H. Adisendjaja and O. Romlah, "Analisis Buku Ajar Sains Berdasarkan Literasi Ilmiah Sebagai Dasar Untuk Memilih Buku Ajar Sains (Biologi)," Semin. Nas. Pendidik. Biol. dan Biol., pp. 1-8, 2007.

[13] W. Syafii and R. M. Yasin, "Problem solving skills and learning achievements through problem-based module in teaching and learning biology in high school," Asian Soc. Sci., vol. 9, no. 12 SPL ISSUE, pp. 220-228, 2013.

[14] N. Alias, D. DeWitt, M. N. A. Rahman, R. B. Gelamdin, R. A. A. Rauf, and S. Siraj, "Effectiveness of the Biology PTechLS Module in a Felda Science Centre," Malaysian Online J. Educ. Technol., vol. 2, no. 4, pp. 32-36, 2014.

[15] A. Yani and R. Adiansyah, "Developing Problem-Based Learning Module For Biotechnology Concepts," J. Pendidik. Sains, vol. 5, no. 2, pp. 46-56, 2017.

[16] S. Sudarisman, "Membangun Karakter Peserta Didik Melalui Pembelajaran Biologi Berbasis Keterampilan Proses," Semin. Nas. Pendidik. Biol. FKIP UNS 2010, pp. $237-$ 243, 2010.

[17] D. Rahmawati, S. Sajidan, and A. Ashadi, "Analysis of problem solving skill in learning biology at senior high school of Surakarta," J. Phys. Conf. Ser., vol. 1006, no. 1, 2018.

[18] H. E. Pratiwi, H. Suwono, and N. Handayani, "Pengembangan Modul Pembelajaran Biologi Berbasis Hybrid Learning untuk Meningkatkan Kemampuan Berpikir Kritis dan Hasil Belajar Siswa Kelas XI,”Jurnalonline. um. ac. id, pp. 1-12, 2014. 